Економічні науки: збірник наукових праџь Луцького національного технічного університету. - Серія "Регіональна економіка". - Випуск 15 (59). - Редкол.: відп. ред. д.е.н., професор Л.Л. Ковальська. - Луцьк: ІВВ Луцького НТУ, 2018. - 292 с.

УДК 330.1:332.13

Вахович I.М., д.е.н., професор, завідувач кафедри фінансів, банківської справи та страхування

Камінська I.M., к.е.н., доцент

Мишко О.А., к.е.н., доцент

Камінська Д.В., магістрант

Луцький національний технічний університет

\title{
КАПІТАЛІЗАЦІЯ НА МІКРО- І МЕЗОРІВНЯХ: ВЗАЄМООБУМОВЛЕНІСТЬ, ПРОБЛЕМИ, МЕТОДИ ПІДВИЩЕННЯ
}

У статті розглянуто вплив та соціально-економічну значимість діяльності підприємств різних сфер виробництва на капіталізацію економіки регіону. Систематизовано роль підприємств у капіталізації економіки регіону згідно основних функцій. Також у межах кожної з функцій визначено основні проблеми капіталізації підприємств в сучасних умовах, що у результаті перешкоджають капіталізації економік регіонів України. Обгрунтовано основні напрями та методи капіталізації підприємств на шляху капіталізації економіки регіону.

Ключові слова: підприємство, економіка регіону, капіталізація, капіталізація підприємства, капіталізація економіки регіону.

\section{Vachovych I., Kaminska I., Myshko O., Kaminska D. CAPITALIZATION ON MICRO- AND MESO-LEVEL: CROSS- CUTTING, PROBLEMS, METHODS OF IMPROVEMENT}

Increased practical interest to the problem of capitalization in recent years, as well as the theoretical and methodological ambiguity of a number of issues determine the feasibility of further scientific research in this area, primarily, the capitalization of the economy of the region and its primary links - enterprises. The purpose of this article is to investigate and to prove the interconnection between capitalization of enterprise and capitalization of the region's economy, to establish their problems in current conditions and to determine the methods of improving the situation. The methodological base of the research was the developments of economic science according to the study of entrepreneurial activity, economics of enterprise, regional development, regional economy and capitalization. Results. The influence and socio-economic significance of activity of enterprises of various spheres of production on capitalization of the region's economy is considered. The role of enterprises in capitalization of the region's economy according to its 
Економічні науки: збірник наукових праиь Луиького національного технічного університету. - Серія "Регіональна економіка". - Випуск 15 (59). - Редкол.: відп. ред. д.е.н., професор Л.Л. Ковальська. - Луцьк: ІВВ Луцького НТУ, 2018. - 292 с.

functions (transformation function; accumulation function; reproductive function; investment function; stimulating function; strategic function; information function; forecast function; distributive function) is systematized. Also, within each of the functions the main problems of capitalization of enterprises in modern conditions are identified, which ultimately hinder the capitalization of the economies of the regions of Ukraine. The main directions of capitalization of enterprises (effective formation and usage of capital by enterprises; formation of a positive image of enterprises; increasing the investment attractiveness of enterprises; financial restructuring of enterprises) are substantiated on the way of capitalization of the region's economy. The main methods of capitalization of enterprises are proposed. Conclusion. Capitalization as a characteristic of growth at the micro level affects on the parameters of economic growth in the region. Therefore, increasing the level of capitalization of domestic enterprises is an important factor in the development of regional and national economies and overcoming the current economic crisis in Ukraine.

Key words: enterprise, region's economy, capitalization, capitalization of the enterprise, capitalization of the region's economy.

\section{Вахович И., Каминская И., Мишко О., Каминская Д. КАПИТАЛИЗАЦИЯ НА МИКРО- И МЕЗОУРОВНЕ: ВЗАИМООБУСЛОВЛЕННОСТЬ, ПРОБЛЕМЫ, МЕТОДЫ ПОВЫШЕНИЯ}

В статье рассмотрено влияние и социально-экономическую значимость деятельности предприятий различных сфер производства на капитализацию экономики региона. Систематизировано роль предприятий в капитализации экономики региона по основным функциям. Также в рамках каждой из функций определены основные проблемы капитализации предприятий в современных условиях, которые в результате препятствуют капитализации экономик регионов Украины. Обоснованы основные пути и методы капитализации предприятий на пути капитализации экономики региона.

Ключевые слова: предприятие, экономика региона, капитализация, капитализация предприятия, капитализация экономики региона.

\section{Постановка проблеми у загальному вигляді і її зв'язок 3 важливими науковими та практичними завданнями. Категорію капіталізація у наукових колах спочатку використовували як характеристику фондового ринку. Нині іï широко застосовують щодо публічних акціонерних товариств, а також щодо регіональної і національної економік, що обумовлено багатогранністю та безліччю форм iii прояву в}


Економічні науки: збірник наукових праиь Луиького національного технічного університету. - Серія "Регіональна економіка". - Випуск 15 (59). - Редкол.: відп. ред. д.е.н., професор Л.Л. Ковальська. - Луцьк: ІВВ Луцького НТУ, 2018. - 292 с.

сучасних умовах господарювання. Посилений практичний інтерес до цієї проблематики в останні роки, а також теоретикометодична неоднозначність ряду питань визначають доцільність подальшого наукового пошуку в сфері капіталізації, насамперед, капіталізації економіки регіону i iï первинної ланки підприємства.

Аналіз останніх досліджень, у яких започатковано вирішення проблеми. Окремі питання капіталізації на рівні підприємств є об'єктом дослідження таких вітчизняних i іноземних науковців, як Д. Алєксєєв, І. Булєєв, Н. Брюховецька, А. Воронін, Ш. Ідрисов, В. Казинцев, І. Кіршин, П. Корзьонок, К. Курілов, Є. Россоха, Л. Самсонова, Н. Щербакова, В. Янчевський та інших. Проблематику капіталізації на регіональному рівні досліджують А. Амосов, І. Вахович, Г. Возняк, В. Геєць, А. Гриценко, М. Дєдкова, М.Козоріз, Н. Кухарська, Ю. Лищикова, Т. Малова, С. Мочерний, В. Овчинніков, О. Овчиннікова, Ю. Рожков, С. Сіліфонкіна, I. Школьник, С. Шумська та інші. Беззаперечно, їх дослідження $\epsilon$ вагомим внеском у розвиток теоретико-методологічних i прикладних засад капіталізації на мікро- і мезорівнях. Разом 3 тим, спостерігаються розбіжності у концептуальних i методичних підходах науковців до вивчення окремих аспектів у зазначеній проблематиці. Також спостерігається брак досліджень у напрямі встановлення причинно-наслідкових зв’язків між капіталізацією підприємства та капіталізацією економіки регіону й доцільністю одночасного вирішення проблем на усіх рівнях.

Цілі статті. Так, основна мета дослідження полягає в 3'ясуванні ролі й впливу підприємницьких структур на капіталізацію економіки регіону, визначенні проблем та методів поліпшення поточної ситуації.

Виклад основного матеріалу дослідження 3 повним обгрунтуванням отриманих наукових результатів. Капіталізація є складним багаторівневим процесом. Зрозумілим $\epsilon$ той факт, що забезпечити капіталізацію економіки регіону можливо на основі капіталізації соціально-економічних систем 
Економічні науки: збірник наукових праџь Луцького національного технічного університету. - Серія "Регіональна економіка". - Випуск 15 (59). - Редкол.: відп. ред. д.е.н., професор Л.Л. Ковальська. - Луиьк: ІВВ Луиького НТУ, 2018. - 292 с.

нижчого рівня, тобто регіональних суб'єктів господарювання, насамперед, підприємств (рис. 1). Саме підприємства є ключовими каталізаторами для прискорення темпів росту капіталізації економіки будь-якого рівня (регіонального, національного), адже їх діяльність сприяє соціальноекономічному розвитку, досягненню достойного рівня життя населення, нарощенню виробничого, фінансового, індустріального, інтелектуального й науково-технічного потенціалу території [1, с. 105].

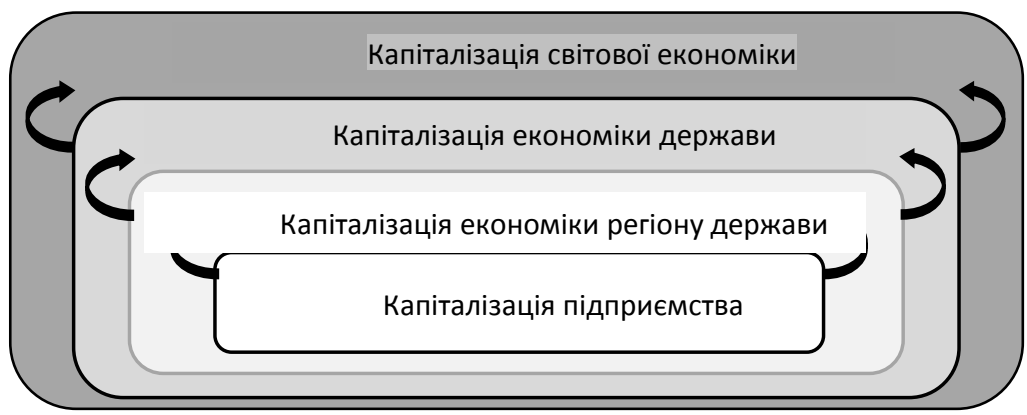

Рис. 1. Модель капіталізації світової економіки

Капіталізація підприємства - це процес нарощення власного його капіталу (потенціалу) всіма можливими методами та, насамперед, шляхом реінвестування прибутку, формування позитивного іміджу та надійної репутації, нарощування інтелектуального капіталу, виходу на фондовий ринок, з метою забезпечення приросту прибутковості, динамічного розвитку, розширення підприємницької діяльності й на цій основі отримання додаткових соціально-економічних вигід (ефекту), що загалом сприятиме росту вартості бізнесу [2, с. 251].

Капіталізація відображає інвестиційну, фінансову спроможність та кредитоспроможність підприємства. Підвищення рівня капіталізації підприємства вирішує проблеми фінансування його економічного розвитку, формування додаткових джерел капіталу, розширення масштабів діяльності й виходу на нові ринки, у тому числі й іноземні. 
Економічні науки: збірник наукових праџь Луцького національного технічного університету. - Серія "Регіональна економіка". - Випуск 15 (59). - Редкол.: відп. ред. д.е.н., професор Л.Л. Ковальська. - Луиьк: ІВВ Луиького НТУ, 2018. - 292 с.

\section{Щоб підприємства були реальними інструментами} капіталізації економіки регіону, потрібно чітко розуміти значення та їх соціально-економічну роль у різних сферах суспільного виробництва (таблиця 1). Окрім того, розвиток підприємств за певним окремим видом економічної діяльності чи сферою суспільного виробництва позитивно впливає на розвиток підприємств у інших сферах виробництва та активізує його.

Таблиця 1

Вплив діяльності підприємств різних сфер

виробництва на капіталізацію економіки регіону

\begin{tabular}{|c|c|c|}
\hline \multicolumn{2}{|c|}{$\begin{array}{c}\text { Підприємства за сферами } \\
\text { виробництва }\end{array}$} & $\begin{array}{c}\text { Роль підприємств у капіталізації } \\
\text { економіки регіону }\end{array}$ \\
\hline \multirow[t]{2}{*}{$\begin{array}{c}\text { Підприємства } \\
\text { сфери } \\
\text { матеріального } \\
\text { виробництва }\end{array}$} & $\begin{array}{l}\text { Підприємства } \\
\text { у сфері } \\
\text { виробництва } \\
\text { матеріальних } \\
\text { благ }\end{array}$ & $\begin{array}{l}\text { Забезпечують виробництво матеріальни } \\
\text { благ, призначених для використання як } \\
\text { сфері матеріального виробництва в якос } \\
\text { засобів виробництва (продукція виробничс } \\
\text { технічного призначення), так й дл } \\
\text { використання у у сфері } \\
\text { споживання особистог } \\
\text { споживання). }\end{array}$ \\
\hline & $\begin{array}{l}\text { Підприємства } \\
\text { у сфері } \\
\text { надання } \\
\text { послуг } \\
\text { матеріального } \\
\text { характеру }\end{array}$ & $\begin{array}{l}\text { Забезпечують матеріальні умови життя } \\
\text { населення та кінцевими результатами їх } \\
\text { функціонування є матеріальні послуги } \\
\text { (торгівельні, транспортні, житлово- } \\
\text { комунальні послуги; послуги громадського } \\
\text { харчування; послуги з обслуговування } \\
\text { ремонту автомобілів, годинників, одягу, } \\
\text { взуття; послуги зі створення підприємств, } \\
\text { приватизації; аудиторські послуги). }\end{array}$ \\
\hline \multirow[t]{2}{*}{$\begin{array}{l}\text { Підприємства } \\
\text { сфери } \\
\text { нематеріаль- } \\
\text { ного } \\
\text { виробництва }\end{array}$} & $\begin{array}{c}\text { Підприємства у } \\
\text { сфері } \\
\text { виробництва } \\
\text { нематеріальних } \\
\text { благ }\end{array}$ & $\begin{array}{lcc}\text { Забезпечують } & \text { розвиток наукомісткост } \\
\text { виробництва, } & \text { інтелектуального } \\
\text { культурного } & \text { потенціалу } \\
\text { формування } & \text { засобів кегіону } \\
\text { сучасного інфонікації } \\
\text { розвитку економіки регіону. }\end{array}$ \\
\hline & \begin{tabular}{|} 
Підприємства \\
сфери надання \\
послуг \\
нематеріального \\
характеру
\end{tabular} & $\begin{array}{l}\text { Забезпечують надання нематеріальни } \\
\text { послуг (освітні, спортивно-оздоровч } \\
\text { бухгалтерські, юридичні, страхові послуги } \\
\text { послуги у сфері охорони здоров' } \\
\text { відпочинку тощо). }\end{array}$ \\
\hline
\end{tabular}


Економічні науки: збірник наукових праиь Луиького національного технічного університету. - Серія "Регіональна економіка". - Випуск 15 (59). - Редкол.: відп. ред. д.е.н., професор Л.Л. Ковальська. - Луцьк: ІВВ Луцького НТУ, 2018. - 292 с.

Очевидно, що для капіталізації економіки та забезпечення динамічного розвитку економіки регіону, важливо забезпечити розвиток підприємств різних сфер і секторів суспільного виробництва, видів економічної діяльності тощо. Проте внесок і значення підприємств різних сфер виробництва у капіталізацію економіки регіону не $є$ рівнозначним і однонаправленим. Разом 3 тим, комплексність і цілковитість розвитку економіки регіону, максимізації іiі капіталізації визначатимуться рівнем розвитку підприємств різних видів економічної діяльності у всіх сферах суспільного виробництва [1, с. 105].

Відповідно, наявність кореляції між рівнями капіталізації підприємств регіону та рівнями капіталізації його економіки не викликає сумнівів. Так і практика засвідчує, що високими рівнями капіталізації економіки характеризуються саме ті держави, чи їх регіони, на території яких розміщені підприємства високого рівня капіталізації. Така вагома роль капіталізації підприємств у капіталізації економіки регіону пояснюється сукупністю основних іï функцій [2, с. 251; 3, c. 141]: трансформаційна функція; накопичувальна функція; відтворювальна функція; інвестиційна функція; стимулююча функція; стратегічна функція; інформаційна функція; прогнозна функція; розподільча функція.

У таблиці 2 систематизовано i визначено роль капіталізації підприємств у капіталізації економік регіонів згідно основних iï функцій та виділено проблеми, що перешкоджають і не дозволяють забезпечувати капіталізацію економік регіонів України.

Наведені у таблиці 2 проблеми капіталізації на нинішньому етапі розвитку економік регіонів України перешкоджають належному i достатньому залученню підприємницького потенціалу регіонів України в сучасній ринковій економіці, тому він неналежним чином реалізує свої переваги на шляху капіталізації економік регіонів держави. 
Економічні науки: збірник наукових праџь Луцького національного технічного університету. - Серія "Регіональна економіка". - Випуск 15 (59). - Редкол.: відп. ред. д.е.н., професор Л.Л. Ковальська. - Луцьк: ІВВ Луиького НТУ, 2018. - 292 с.

Таблиця 2

Систематизація ролі підприємств у капіталізації економіки регіонів та наявних проблем згідно основних функцій

\begin{tabular}{|c|c|c|}
\hline $\begin{array}{c}\text { Функції } \\
\text { капіталізації }\end{array}$ & $\begin{array}{c}\text { Роль підприємств у } \\
\text { капіталізації економіки } \\
\text { регіону }\end{array}$ & $\begin{array}{c}\text { Проблеми капіталізації } \\
\text { на нинішньому етапі } \\
\text { розвитку }\end{array}$ \\
\hline 1 & 2 & 3 \\
\hline $\begin{array}{c}\text { Відтворю- } \\
\text { вальна }\end{array}$ & $\begin{array}{c}\text { Саме підприємства } \\
\text { забезпечують відтворення } \\
\text { фізичного і фінансового } \\
\text { капіталу, поліпшення } \\
\text { добробуту власників і } \\
\text { працівників підприємства, } \\
\text { структурній перебудові } \\
\text { економіки. }\end{array}$ & $\begin{array}{c}\text { Високий рівень ухилення } \\
\text { від сплати податків та і в } \\
\text { цілому значний рівень } \\
\text { тіньової економіки. }\end{array}$ \\
\hline Розподільча & $\begin{array}{c}\text { Забезпечує переміщення } \\
\text { капіталу між сферами та } \\
\text { суб'єктами регіональної } \\
\text { економіки. } \\
\end{array}$ & $\begin{array}{c}\text { Скорочення чисельності } \\
\text { підприємницьких } \\
\text { структур. }\end{array}$ \\
\hline Інформачійна & $\begin{array}{c}\text { Безпосередня } \\
\text { поінформованість про стан } \\
\text { підприємництва та } \\
\text { економічний розвиток на } \\
\text { мікро-, мезо- і макрорівнях, а } \\
\text { також можливі перспективи. }\end{array}$ & $\begin{array}{c}\text { Неналежна фінансова } \\
\text { грамотність керівництва і } \\
\text { менеджменту підприємств. } \\
\text { Відсутність достовірної і } \\
\text { повної інформації щодо } \\
\text { рівня капіталізації } \\
\text { основних суб'єктів } \\
\text { господарювання. }\end{array}$ \\
\hline $\begin{array}{c}\text { Накопичу- } \\
\text { вальна }\end{array}$ & $\begin{array}{c}\text { Підприємства створюють } \\
\text { можливості накопичення } \\
\text { капіталу шляхом залучення } \\
\text { інвестицій, позичкового } \\
\text { капіталу, капіталізації } \\
\text { прибутку, безоплатно } \\
\text { отриманих і благодійних } \\
\text { внесків. Підприємства } \\
\text { наповнюють бюджети усіх } \\
\text { рівнів різного роду } \\
\text { надходження та загалом є } \\
\text { основними } \\
\text { формоутворювачами бюджетів. }\end{array}$ & $\begin{array}{c}\text { Високі інфляційні ризики. } \\
\text { Висока ризиковість } \\
\text { накопичення капіталу і } \\
\text { його використання у } \\
\text { реальному секторі } \\
\text { економіки. } \\
\text { Низький рівень захисту } \\
\text { прав власності. }\end{array}$ \\
\hline
\end{tabular}


Економічні науки: збірник наукових праџь Луцького національного технічного університету. - Серія "Регіональна економіка". - Випуск 15 (59). - Редкол.: відп. ред. д.е.н., професор Л.Л. Ковальська. - Луцьк: ІВВ Луиького НТУ, 2018. - 292 с.

Продовження таблиці 2

\begin{tabular}{|c|c|c|}
\hline 1 & 2 & 3 \\
\hline $\begin{array}{c}\text { Трансформа- } \\
\text { ичийна }\end{array}$ & $\begin{array}{c}\text { Безпосередньо в процесах } \\
\text { виробничо-господарської } \\
\text { діяльності підприємств } \\
\text { відбувається перетворення } \\
\text { капіталу з одного виду і форми } \\
\text { в інші. }\end{array}$ & $\begin{array}{c}\text { Недостатній рівень } \\
\text { використання } \\
\text { потенціалу акціонерних } \\
\text { товариств, низький } \\
\text { рівень використання } \\
\text { фондових бірж і загалом } \\
\text { неналежний рівень } \\
\text { організації ринку цінних } \\
\text { паперів. } \\
\end{array}$ \\
\hline Інвестииійна & $\begin{array}{c}\text { Інвестиційна привабливість } \\
\text { підприємств у регіоні } \\
\text { обумовлює і інвестиційну } \\
\text { привабливість регіону, формує } \\
\text { позитивний імідж регіону та } \\
\text { його бренд. Інвестиції є } \\
\text { каталізатором економічного } \\
\text { розвитку підприємства та } \\
\text { регіону загалом. }\end{array}$ & $\begin{array}{c}\text { Низька інвестиційна } \\
\text { активність підприємств. } \\
\text { Недовіра з боку } \\
\text { іноземних інвесторів до } \\
\text { вітчизняного } \\
\text { законодавства. }\end{array}$ \\
\hline Стимулююча & $\begin{array}{c}\text { Реалізується шляхом } \\
\text { фінансування інноваційних } \\
\text { проектів. } \\
\text { Стимулює залучення інвестицій } \\
\text { в економіку регіону. }\end{array}$ & $\begin{array}{c}\text { Відсутність дієвих } \\
\text { стимулів у підприємств } \\
\text { через високі ризики та } \\
\text { існування безлічі } \\
\text { перешкод у процесі їх } \\
\text { розвитку. Відсутність } \\
\text { належного державного } \\
\text { стимулювання розвитку } \\
\text { підприємництва. } \\
\end{array}$ \\
\hline Стратегічна & $\begin{array}{c}\text { Дозволяє оцінити перспективні } \\
\text { сфери економічної діяльності } \\
\text { регіону. }\end{array}$ & $\begin{array}{c}\text { Існує ймовірність } \\
\text { похибок через } \\
\text { нестабільність } \\
\text { економічної ситуаціі. } \\
\end{array}$ \\
\hline Прогнозна & $\begin{array}{c}\text { Рівень капіталізації } \\
\text { підприємств в регіоні слугує } \\
\text { індикатором його майбутнього } \\
\text { стану та визначає тенденції } \\
\text { розвитку регіону. }\end{array}$ & $\begin{array}{c}\text { Існує ймовірність } \\
\text { похибок через } \\
\text { нестабільність } \\
\text { економічної ситуації. }\end{array}$ \\
\hline
\end{tabular}

Низький рівень капіталізації обмежує ринкові позиції підприємств і негативно впливає на конкурентні позиції регіону і держави в цілому, зменшує потоки інвестицій у сфери 
Економічні науки: збірник наукових праиь Луиького національного технічного університету. - Серія "Регіональна економіка". - Випуск 15 (59). - Редкол.: відп. ред. д.е.н., професор Л.Л. Ковальська. - Луцьк: ІВВ Луцького НТУ, 2018. - 292 с.

матеріального й нематеріального виробництва і перешкоджає їх розвитку [4, с. 24]. Тому соціально-економічний розвиток регіону в сучасних умовах повинен базуватися на активній реалізації усіх можливостей інтенсивного розвитку підприємництва і спроможності ефективно використовувати підприємницький потенціал [1, с. 109].

На нашу думку, основними напрямами капіталізації підприємств є (таблиця 3):

1) ефективне формування та використання капіталу на підприємствах;

2) формування позитивного іміджу підприємств;

3) підвищення інвестиційної привабливості підприємств;

4) фінансова реструктуризація підприємств.

Реалізація вищенаведених напрямів і виокремлених за ними методів капіталізації підприємств дозволить вирішити фундаментальні проблеми розвитку як підприємництва, так i економіки на різних рівнях. Однак як засвідчує практика, лише комплексний підхід, що базуватиметься на застосуванні усіх можливих методів та стосуватиметься усіх напрямів діяльності підприємства, забезпечить підвищення рівня його капіталізації. Комплексність i широке застосування методів підвищення капіталізації підприємства означає досягнення синергетичного ефекту від їх використання [5, с. 279]. При цьому під час застосування сукупності вищенаведених методів доцільним $€$ проведення моніторингу їх дієвості, що дозволить вчасно отримати необхідну інформацію та відреагувати на неї, підкоректувати заходи підвищення рівня капіталізації підприємства i, як результат, капіталізації економіки регіону.

Загалом синергетичний ефект капіталізації підприємства у довгостроковому розвитку економіки регіону проявляється у: нагромадженні і консолідації капіталу; залученні стратегічних інвесторів; цілеспрямованому розвитку економіки регіону на основі власного капіталу; задоволенні потреб населення регіону у матеріальних i нематеріальних благах та послугах; забезпеченні соціальної стабільності й соціального добробуту. 
Економічні науки: збірник наукових праџь Луцького національного технічного університету. - Серія "Регіональна економіка". - Випуск 15 (59). - Редкол.: відп. ред. д.е.н., професор Л.Л. Ковальська. - Луцьк: ІВВ Луиького НТУ, 2018. - 292 с.

Таблиця 3

Напрями та методи капіталізації підприємств

\begin{tabular}{|c|c|}
\hline $\begin{array}{c}\text { Напрями } \\
\text { підвищення } \\
\text { капіталізації } \\
\text { підприємств }\end{array}$ & Методи підвищення капіталізації підприємств \\
\hline $\begin{array}{c}\text { Ефективне } \\
\text { формування та } \\
\text { використання } \\
\text { капіталу на } \\
\text { підприємстві }\end{array}$ & $\begin{array}{l}\text { 1. Удосконалення амортизаційної політики } \\
\text { підприємств. } \\
\text { 2. Оптимізація товарно-матеріальних запасів. } \\
\text { 3. Технічне переозброєння підприємств і } \\
\text { технологічна модернізація. } \\
\text { 4. Розвиток інтелектуального капіталу. } \\
\text { 5. Ріст капітальних інвестицій. } \\
\text { 6. Розширення ринків збуту. }\end{array}$ \\
\hline $\begin{array}{l}\text { Формування } \\
\text { позитивного } \\
\text { іміджу } \\
\text { підприємств } \\
\end{array}$ & $\begin{array}{l}\text { 1. Підвищення курсової вартості акцій. } \\
\text { 2. Розробка і просування власного бренду. } \\
\text { 3. Активна маркетингова політика. } \\
\text { 4. Нарощування нематеріальних активів. }\end{array}$ \\
\hline $\begin{array}{l}\text { Підвищення } \\
\text { інвестиційної } \\
\text { привабливості } \\
\text { підприємств }\end{array}$ & $\begin{array}{l}\text { 1. Розробка і реалізація інвестиційної стратегії } \\
\text { підприємства. } \\
\text { 2. Реалізація інноваційно-інвестиційних } \\
\text { проектів. } \\
\begin{array}{ll}\text { 3. Інтеграція вітчизняних підприємств із } \\
\text { зарубіжними партнерами. }\end{array}\end{array}$ \\
\hline $\begin{array}{c}\text { Фінансова } \\
\text { реструктуризація } \\
\text { підприємств }\end{array}$ & $\begin{array}{l}\text { 1. Оптимізація фінансових потоків. } \\
\text { 2. Максимізація доходності інвестованого } \\
\text { капіталу. } \\
\text { 3. Мінімізація витрат на залучення капіталу } 3 \\
\text { різних джерел. } \\
\text { 4. Оптимізація співвідношення між власним і } \\
\text { позичковим капіталом. } \\
\text { 5. Вихід на вітчизняний і міжнародний } \\
\text { фондовий ринок. }\end{array}$ \\
\hline
\end{tabular}

Висновки. Отже, капіталізація як характеристика росту на мікрорівні впливає на параметри економічного росту регіону [6]. Тому підвищення рівня капіталізації вітчизняних підприємств є важливим фактором розвитку регіональних i 
Економічні науки: збірник наукових праџь Луцького національного технічного університету. - Серія "Регіональна економіка". - Випуск 15 (59). - Редкол.: відп. ред. д.е.н., професор Л.Л. Ковальська. - Луцьк: ІВВ Луиького НТУ, 2018. - 292 с.

національної економік та подолання наявної в Україні економічної кризи. Спостерігається закономірність: взаємодія динаміки капіталізації підприємств і капіталізації економіки регіону здійснюється на основі механізму акселерації.

Проведене дослідження дозволило встановити проблеми капіталізації на рівні підприємства й регіону на нинішньому етапі розвитку України, а також обгрунтувати систему напрямів і методів капіталізації підприємств у довгостроковому розвитку економіки регіону та підвищенні рівня його капіталізації.

1. Камінська І.М., Дорош В.Ю., Мишко О.А. Ідентифікація і роль підприємництва різних сфер виробництва у контексті капіталізації економіки регіону. Економічний форум: науковий журнал. 2018. № 2. C. 104-110. URL: http://lutsk-ntu.com.ua/sites/default/files/ekonomichniy_forum_2.pdf звернення: 10.09.2018).

2. Вахович I.М., Пушкарчук І.М., Мишко О.А. Теоретичні засади капіталізації підприємств в умовах структурної модернізації економіки регіону. Соціально-економічні проблеми сучасного періоду України. 2016. № 6. C. 247-252.

3. Кривов'язюк І.В., Пушкарчук І.М., Волинчук Ю.В. Капіталізація як основа динамічного розвитку підприємств. Економічний форум : науковий журнал. 2017. № 1. C. 135-144. URL: http://lutskntu.com.ua/sites/default/files/u_nomeri_1_2017.pdf. (дата звернення: 10.09.2018).

4. Киршин И.А. Капитализация как синергетический фактор роста постиндустриальной экономики. Учёные заиски Казанского государственного университета. 2005. Т. 147. № 3. С. 19-32.

5. Корзёнок П.В. Методы повышения капитализации предприятий реального сектора экономики. Труды БГТУ. 2017. Серия 5. № 1. С. 278-281.

6. Дедкова М.В. Капитализация и ее влияние на экономический рост (на примере непубличных компаний): автореф. дис. ... канд. экон. наук : 08.00.10. Москва, 2008. 27 с. URL: http://economylib.com/disser/417019/a?\#?page=1. (дата звернення: 10.09.2018). 